\title{
PERILAKU LENTUR BALOK BETON BERTULANG KOMPOSIT BETON NORMAL-BETON NON PASIR TAMPANG T
}

\author{
Yovi Chandra \\ Jurusan Teknik Sipil, Universitas Malikussaleh \\ email:yovicvil@gmail.com
}

\begin{abstract}
Abstrak
Inovasi dan teknologi konstruksi beton sekarang ini sedang mengembangkan penggunaan beton non-pasir sebagai bahan bangunan di mana pembuatannya mudah, cepat dan dapat diaplikasikan pada struktur rumah sederhana. Untuk itu perlu penelitian perilaku dan karakteristik balok komposit antara beton normal dan beton non-pasir dalam memikul beban yang bekerja pada suatu struktur dengan blok tekan beton diusahakan di daerah sayap. Spesimen berupa 3 benda uji yang terdiri dari 1 buah balok T beton normal, 1 buah balok komposit $\mathrm{T}$, dan 1 buah balok $\mathrm{T}$ beton non-pasir dan diuji dengan gaya vertikal yang sama besar pada sepertiga bentang. Beton normal dirancang $f^{\prime} c=20 \mathrm{MPa}$ dan beton non pasir dirancang dengan perbandingan volume semen kerikil 1:2. Data pengujian yang diambil berupa nilai beban, regangan dan lendutan dianalisis sehingga diperoleh kapasitas momen, kekakuan, daktilitas. Melalui pola retak akibat beban statis diperoleh jenis keruntuhannya. Selain itu juga dilakukan penelitian pendukung yaitu pengujian kuat lekat antara baja tulangan dan pengujian gaya geser friksi pada balok T komposit. Hasil pengujian lentur pada balok T BK-1 dan BNP1 dibandingkan terhadap beton $\mathrm{BN}-1$ diperoleh penurunan kapasitas sebesar $1,35 \%$ dan 8,53 \%. Analisis daktilitas balok BK-1 dan BNP-1 bila dibandingkan terhadap balok $\mathrm{BN}-1$ diperoleh penurunan daktilitas sebesar 4,98 \% dan 12,68\%. Penurunan nilai kekakuan lentur balok BK-1 dan BNP1 mencapai $1,46 \%$ dan $6,49 \%$ terhadap balok BN-1. Pola retak balok BN-1, BNP-1 dan BK-1 adalah keruntuhan lentur dimana terjadi retak dimulai dari tengah bentang sampai sepertiga panjang balok dan semakin melebar menuju sumbu netral penampang. Hasil pengujian kuat lekat beton non-pasir dengan tulangan diameter $12 \mathrm{~mm}$ diperoleh sebesar 8,1848 MPa. Hasil pengujian geser friksi menunjukkan kuat geser sebesar $2,111 \mathrm{MPa}$.
\end{abstract}

Kata kunci : Komposit, Kapasitas Momen, Daktilitas, Kekakuan

\section{Pendahuluan}

Inovasi dan teknologi konstruksi beton sampai sekarang ini sedang mengembangkan penggunaan beton non pasir sebagai bahan bengunan dimana pembuatannya lebih mudah dan cepat. Penggunaan beton non-pasir sebagai bahan bengunan dalam konstruksi beton perlu terus dikembangkan. Aplikasi beton non pasir untuk struktur rumah sederhana, mengingat keterbatasan kuat tekannya yang lebih rendah dari beton normal perlu untuk dikembangkan yaitu penggunaan beton komposit pada balok $\mathrm{T}$ dimana plat berupa beton normal sedangkan balok berupa beton non pasir. Penelitian ini diusahakan balok $\mathrm{T}$ komposit bekerja sebagai tampang persegi saja dimana blok tekan terjadi di daerah sayap. Disamping itu dapat diketahui kuat lekatan antara baja tulangan dengan beton non pasir dan besar gaya geser friksi pada balok $\mathrm{T}$ komposit. 
Tujuan penelitian adalah mendapatkan dan membandingkan kemampuan beban maksimum, defleksi dan kapasitas lentur yang terjadi pada balok beton normal (BN-1), non-pasir (BNP-1) dan komposit (BK-1) tampang $\mathrm{T}$, mengetahui besarnya kuat lekat antara baja tulangan dengan beton non-pasir dan gaya geser friksi pada balok $\mathrm{T}$ komposit.

Batasan masalah dalam penelitian adalah: menggunakan spesimen balok bertulang tampang $\mathrm{T}$; beton normal dengan $f^{\prime} c=20 \mathrm{MPa}$ dan beton non-pasir volume kerikil-semen sebesar 2, baja tulangan berdiameter $12 \mathrm{~mm}$ untuk tulangan pokok dan $6 \mathrm{~mm}$ untuk tulangan tekan dan sengkang, spesifikasi berupa balok T dianalisis sebagai balok persegi untuk mengetahui perubahan momen, lendutan, kekakuan dan daktilitas balok, menggunakan 3 sampel benda uji, terdiri dari 1 buah balok $\mathrm{T}$ beton normal, 1 buah balok $\mathrm{T}$ beton non-pasir dan 1 buah balok komposit tampang $\mathrm{T}$ dengan balok dari beton non-pasir dan slab dari beton normal

\section{Tinjauan Pustaka}

Menurut Tjokrodimuljo (1995) bahwa faktor air semen menghasilkan kuat tekan tertinggi hampir sama umtuk perbandingan volume semen yaitu sebesar 0,4. Hasil penelitian oleh Tjokrodimuljo (1995), untuk beton non-pasir yasng dibuat dari agregat buatan lempung bekah asal Cilacap, dengan perbandingan volume agregat semen 4:1 diperoleh kuat tekan sekitar $15 \mathrm{MPa}$. Menurut Subkhannur (2002) kuat tekan beton non pasir dengan kerikil asal Gunung Merapi dengan perbandingan volume semen:agregat 1:2, 1:4, 1:6, 1:8, 1:10 berturut-turut sebesar 29,76 MPa; 20,28 MPa; 16,23 MPa; 8,81 MPa; 5, $26 \mathrm{MPa}$.

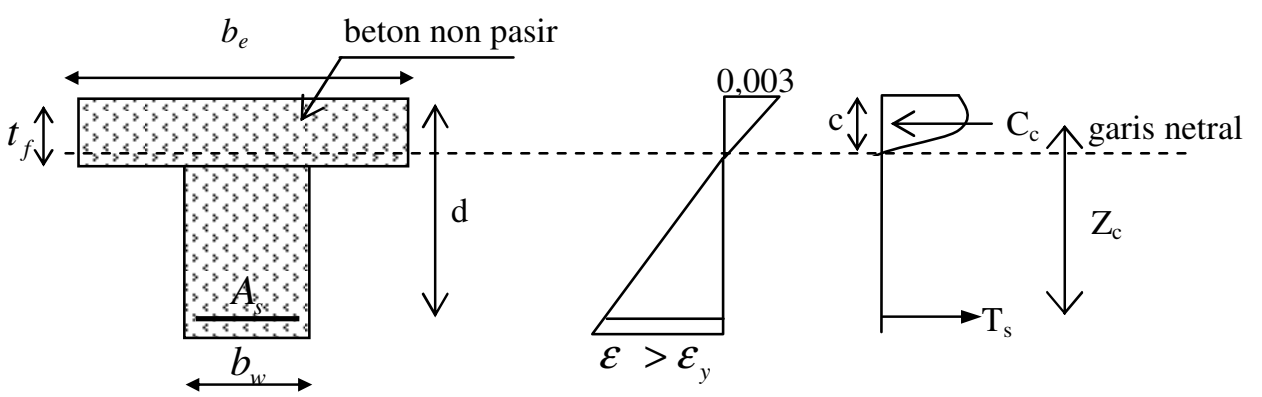

Gambar 1. Diagram tegangan - regangan beton non pasir

Landasan teori pada penelitian ini yaitu untuk kurva hubungan antara tegangan dan regangan beton non-pasir melalui uji tekan silinder bisa didekati dengan persamaan berdasarkan penelitian Carreira dan Chu (Somayaji, 1995):

$$
\frac{f_{c}}{f_{c}^{\prime}}=\frac{\beta\left[\varepsilon / \varepsilon_{c}^{\prime}\right]}{\beta-1+\left(\varepsilon / \varepsilon_{c}^{\prime}\right)^{\beta}}
$$

dimana $\beta=\frac{1}{1-\frac{f^{\prime}{ }_{c}}{\mathcal{E}^{\prime}{ }_{c} E_{i t}}}$

dengan $\beta$ adalah parameter bahan dari bentuk diagram tegangan-regangan ( $\beta \geq 1,0), \varepsilon$ adalah regangan $\varepsilon<\varepsilon_{\mathrm{cu}}$, $\varepsilon_{\mathrm{cu}}$ adalah regangan maksimum, $f \mathcal{c}_{c}$ adalah 
tegangan (MPa), $f^{\prime} c$ adalah tegangan maksimum (MPa), $\varepsilon_{c}^{\prime}$ adalah regangan saat tegangan maksimum $\left(f_{c}^{\prime}\right)$ tercapai, $\mathrm{E}_{\mathrm{it}}$ adalah modulus elastis beton. Analisa lentur balok $\mathrm{T}$ persegi komposit menggunakan pendekatan rumus beton normal sedangkan balok $\mathrm{T}$ beton non pasir diperlihatkan pada Gambar 1.

Dalam analisis menggunakan persamaan dari kurva tegangan-regangan non-pasir Chu and Chareira, sehingga berlaku persamaan berikut:

$$
\begin{aligned}
& C_{c}=b_{w} \int_{0}^{c} f_{1} d y \\
& Z_{c}=\left[b_{w} \int_{0}^{c} f_{1} \cdot y \cdot d y\right] / C_{c}
\end{aligned}
$$

a kondisi $\varepsilon_{s} \geq \varepsilon_{y}$

$$
\begin{aligned}
& T_{s}=A_{s} f_{y} \\
& M_{n}=C_{c}(d-c / 2)
\end{aligned}
$$

Daktilitas menurut Park dan Paulay besarnya daktilitas didefinisikan sebagai displacement ductility factor $\mu$, adalah:

$$
\mu=\delta_{u} / \delta_{y}
$$

dengan $\delta_{u}$ adalah lendutan maksimum pada saat runtuh $(\mathrm{mm}), \delta_{y}$ adalah lendutan pada saat momen leleh tercapai $(\mathrm{mm})$.

Kekakuan menurut Timoshenko didefinisikan sebagai gaya yang dibutuhkan untuk menghasilkan suatu lendutan sebesar satu satuan, adalah:

$$
k=\frac{P_{c r}}{\delta_{c r}}
$$

dengan, $k$ adalah kekakuan lentur $(\mathrm{N} / \mathrm{mm}), P_{\text {cr }}$ adalah beban balok saat retak pertama $(\mathrm{N}), \delta_{\text {cr }}$ adalah lendutan pada saat balok retak pertama $(\mathrm{mm})$.

\section{Metode Penelitian}

Bahan pembuat balok beton normal maupun non-pasir terdiri dari: air bersih dari laboratorium Pusat Ilmu Teknik UGM, semen Portland merek Nusantara, pasir dari kali Boyong Yogyakarta, kerikil dari kali Adem Yogyakarta ukuran 5$20 \mathrm{~mm}$ berupa batu pecah/split, dan baja tulangan berdiameter $12 \mathrm{~mm}$ dan $6 \mathrm{~mm}$. Peralatan Pengujian: timbangan, gelas ukur kapasitas $1000 \mathrm{ml}$, talam baja, kerucut Abrams, tongkat baja, stop watch, VB-Time, alat ukur slump, mil, bekisting benda uji tipe balok $\mathrm{T}$, bekisting geser friksi, bekisting pull out, bekisting silinder, Concrete mixer, vibrator, mesin uji tarik baja, mesin uji tekan Beton, load cell,LVDT, strain gauge baja tarik, strain gauge beton tarik, strain gauge beton tarik tekan, transducer indicator, loading frame, hydraulic jack, perata beban dan tumpuan balok terbuat dari baja profil,

Pengujian dilakukan di laboratorium menggunakan balok $\mathrm{T}$ dengan skala model 1:2. Variasi benda uji, jumlah dan spesifikasi diperlihatkan pada Tabel 1. 
Tabel 1 Jumlah dan spesifikasi benda uji

\begin{tabular}{|l|c|c|c|c|}
\hline \multirow{2}{*}{ Benda uji } & \multirow{2}{*}{ Jumlah } & \multicolumn{2}{|c|}{ Spesifikasi } & \multirow{2}{*}{ Pengujian } \\
\cline { 3 - 4 } & & Balok & Slab & \\
\hline BN (Beton normal)-1 & 1 & normal & normal & Statik \\
\hline BK (Beton Komposit)-1 & 1 & non-pasir & normal & Statik \\
\hline BNP (Beton Non Pasir)-1 & 1 & non-pasir & non-pasir & Statik \\
\hline
\end{tabular}

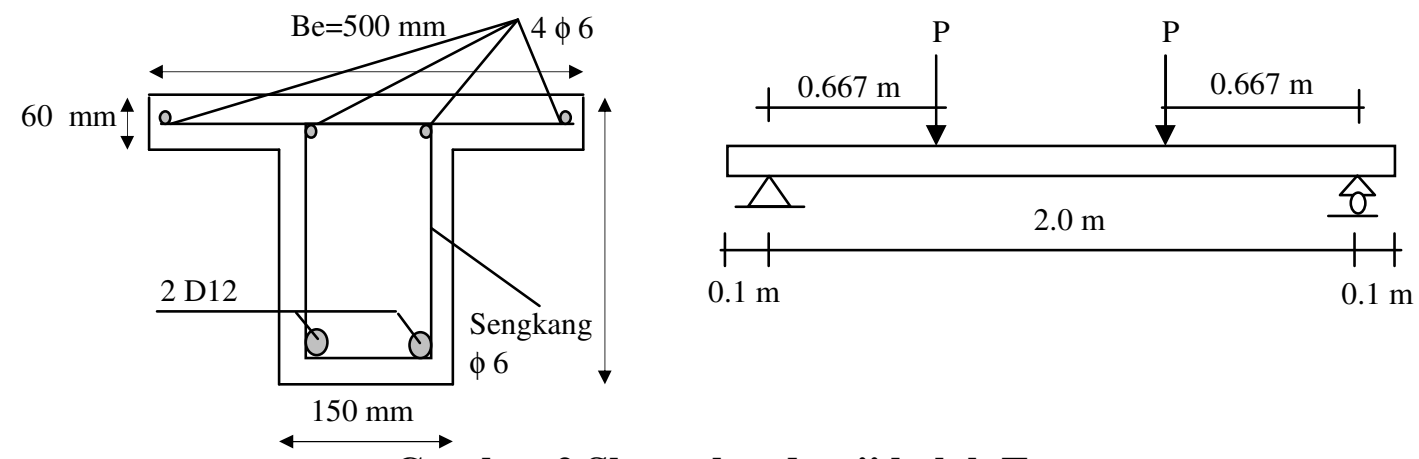

Gambar 2 Sketsa benda uji balok T

Pengujian kuat geser antara beton normal dengan beton non-pasir seperti yang ditunjukkan pada Gambar 3.

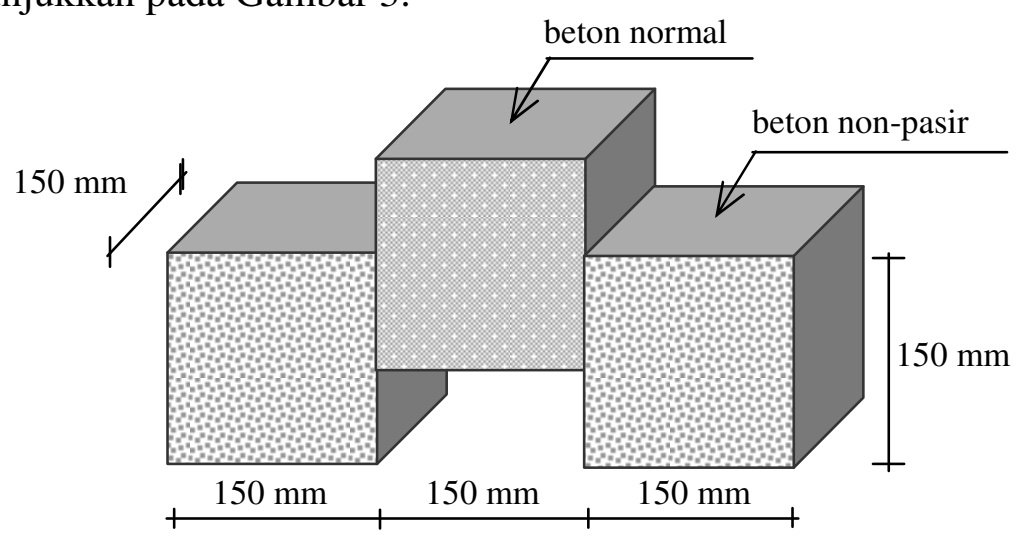

Gambar 3. Sketsa benda uji kuat geser beton

Bentuk dan ukuran benda uji kuat pul out beton non-pasir dapat dilihat pada Gambar 4.

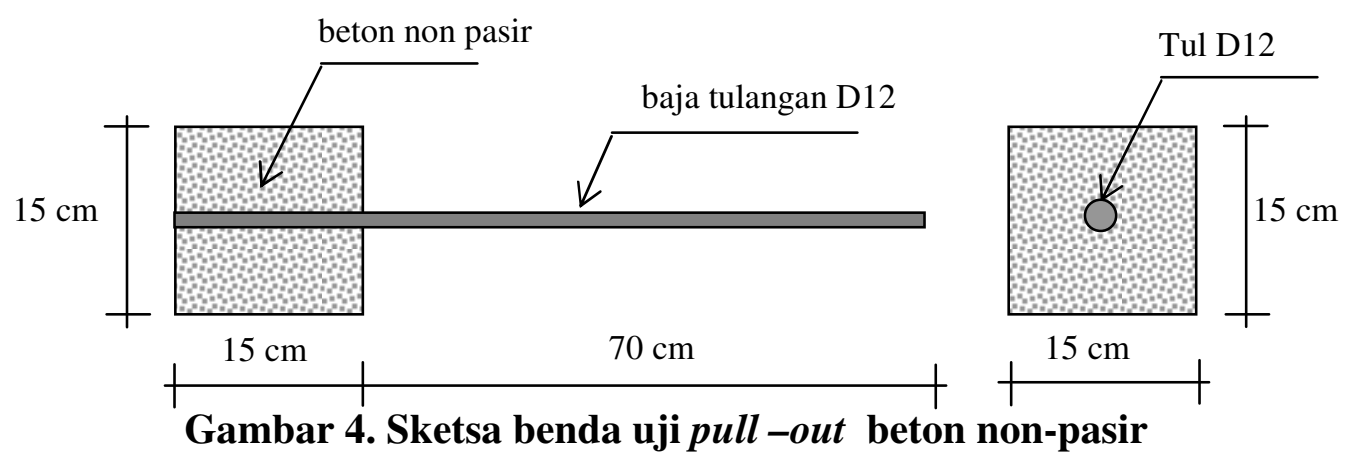


Pengujian ini dilakukan setelah balok beton berumur 28 hari. Sketsa pengujian balok beton dapat dilihat pada Gambar 5. Pengujian dilakukan dengan panjang bentang (jarak tumpuan-tumpuan) $2 \mathrm{~m}$ dengan beban titik sebanyak 2 buah, masing-masing berjarak 0,677 $\mathrm{m}$ dari tumpuan seperti pada Gambar 2 . Beban dilakukan dengan besar beban sedikit demi sedikit dinaikkan dan selama pembebanan dicatat besar beban dan lendutannya melalui transducer indicator. Pembebanan dihentikan sampai beban tidak dapat naik dan lendutan semakin besar.

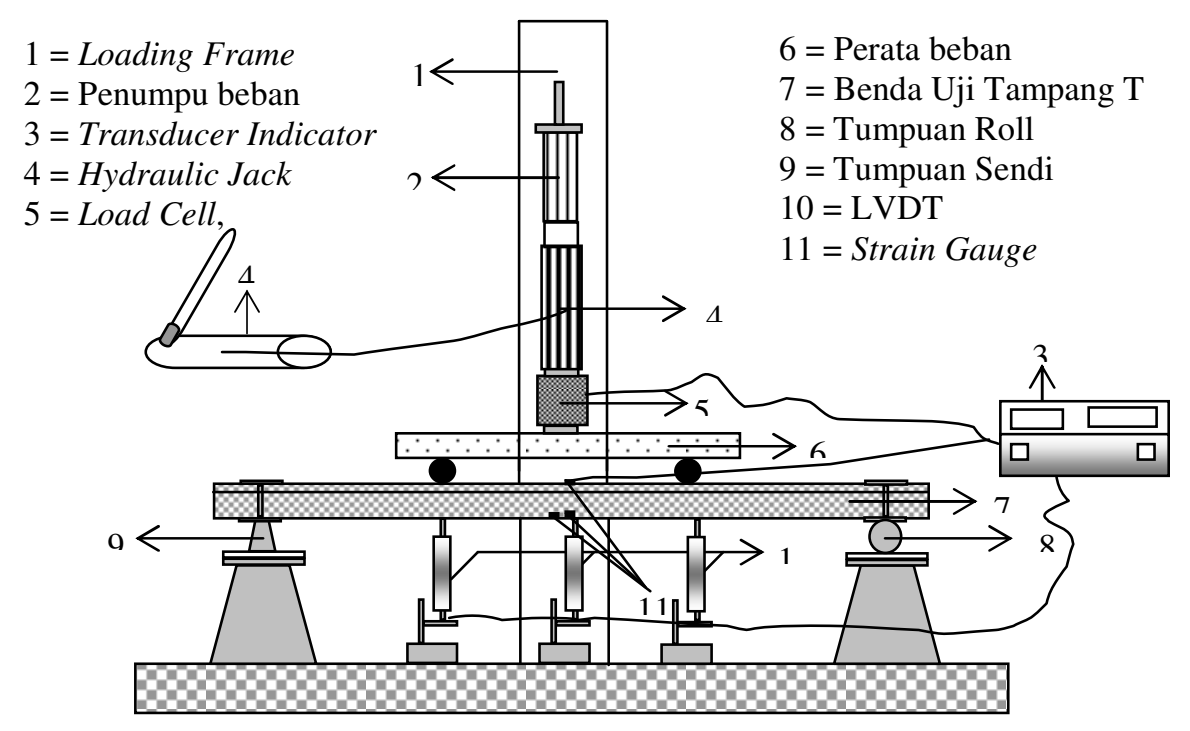

Gambar 5. Setting Up Pengujian Balok

Pengujian kuat lekat antara baja tulangan dengan beton dilakukan berdasarkan SNI:03-4809-1998. Setelah benda uji berumur 28 hari dilakukan pull out test, dengan menggunakan mesin uji serbaguna UTM (Universal Testing Machine), kecepatan penambahan beban maksimum $22 \mathrm{kN} /$ menit kemudian dihentikan bila tercapai titik leleh baja tulangan atau tulangan telah bergeser minimum 2,5 mm. Pengujian geser friksi dilakukan dengan meggunakan mesin Uji Tekan Beton (Compression Testing Test) dengan memberi pelat baja untuk mengunci dan mengakukan benda uji tersebut. Keduan kubus beton non-pasir dipasang dial gauge pada bagian atasnya, dan bagian atasnya kubus beton normal yang diberi beban (akan ditekan) secara bertahap-tahap dan dicatat pergeseran dan beban sampai kedua bidang geser kubus retak

\section{Hasil Dan Pembahasan}

Agregat halus: Pasir alami dengan modulus halus butir 2,667\%, kadar air 5,377\%, gradasi termasuk zona III (agregat agak kasar), berat jenis 2,924 gr/cc, penyerapan 1,091\% air, kandungan lumpur 1,075\%, Agregat halus dinyatakan memenuhi persyaratan untuk membuat beton. Agregat kasar: batu pecah split dengan modulus halus butir $2,878 \%$, berat satuan $1,352 \mathrm{t} / \mathrm{m}^{3}$, berat jenis 2,581 gr/cc, penyerapan air 4,609\%, dan nilai keausan $72,645 \%$, sehingga agregat kasar dinyatakan memenuhi persyaratan untuk membuat beton. Hasil uji silinder beton normal dan non-pasir umur 28 hari. Hasil rerata dapat dilihat pada Tabel 2. 
Tabel 2 Hasil uji tekan silinder rerata beton

\begin{tabular}{|l|c|c|c|c|}
\hline \multicolumn{1}{|c|}{$\begin{array}{c}\text { Benda Uji } \\
\text { Silinder }\end{array}$} & $\begin{array}{c}\text { Tegangan maks } \\
(\mathrm{Mpa})\end{array}$ & $\begin{array}{c}\text { Regangan } \\
\text { maks }\end{array}$ & $\begin{array}{c}\text { Eit } \\
(\mathrm{Mpa})\end{array}$ & Keterangan \\
\hline Sil 3-1, 3-2, 4-1, 4-2 & 18,045 & 0,001496 & 17837 & BNP-1 \\
\hline Sil 6-1, 6-2, 6-3 & 17,148 & 0,001471 & 16643 & BK-1 \\
\hline Sil 11, 12 & 25,476 & 0,002058 & 23406 & BN-1 \\
\hline Sil 10 & 24,238 & 0,002242 & 22554 & BK-1 \\
\hline
\end{tabular}

Nilai tegangan, regangan dan modulus elastisitas dari masing-masing balok akan digunakan untuk menganalisis pengujian balok BN-1, BNP-1 dan BK-1 . Hasil pengujian silinder untuk BNP-1 menggunakan kurva idealisasi dari persamaan Chu dan Careira dapat dilihat pada Gambar 6.

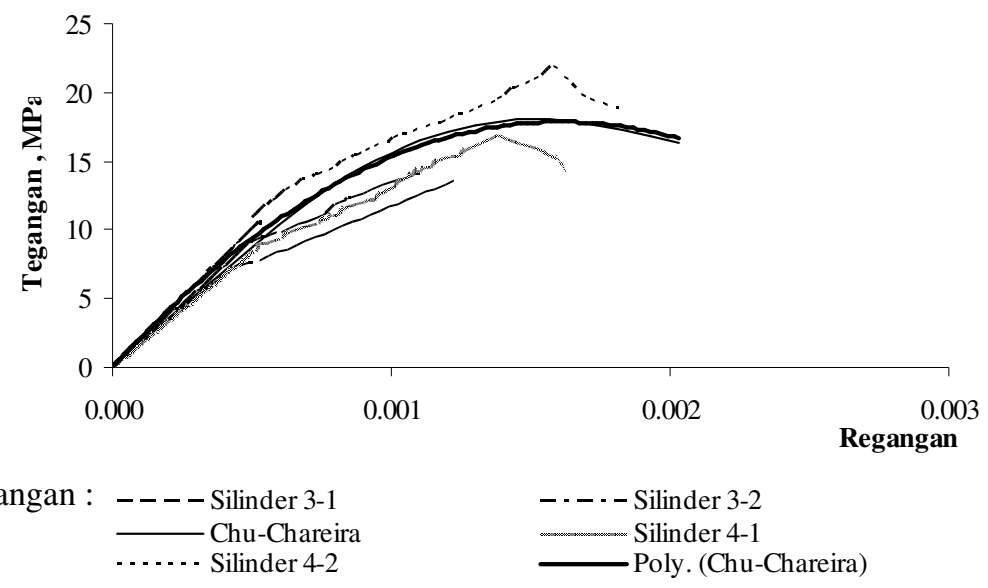

\section{Gambar 6. Grafik tegangan-regangan hasil uji tekan silinder untuk BNP-1}

Hasil uji tarik baja rerata yang digunakan adalah diameter D12 dan D6 dilihat dalam Tabel 3 dengan masing-masing 3 benda uji.

Tabel 3. Tegangan leleh dan modulus elastis baja rerata D6 mm dan D12 mm

\begin{tabular}{|l|c|c|c|}
\hline $\begin{array}{c}\text { Rerata 3 sampel } \\
\text { benda uji }\end{array}$ & $\begin{array}{c}\text { Tegangan Leleh } \\
(\mathrm{MPa})\end{array}$ & $\begin{array}{c}\text { Tegangan Ultimit } \\
(\mathrm{MP})\end{array}$ & $\begin{array}{c}\text { Modulus Elastisitas } \\
(\mathrm{MPa})\end{array}$ \\
\hline Diameter 6 & 299,67 & 395,07 & 151729,67 \\
\hline Diameter 12 & 493,11 & 666,91 & 180053,67 \\
\hline
\end{tabular}

Besar nilai tegangan leleh, regangan leleh, tegangan ultimit dan regangan ultimit diameter $6 \mathrm{~mm}$ dan $12 \mathrm{~mm}$ akan digunakan untuk menganalisis kapasitas balok BN-1, BNP-1 dan BK-1. Hasil pengujian pull out diperoleh data kuat lekat rerata sebesar $0,409 \mathrm{MPa}$ dan pada perpanjangan sebesar $0,25 \mathrm{~mm}$ dengan beban maksimum penarikan sebesar 45983,333 N sehingga kelebihan gaya tarik akibat beban luar pada balok BNP-1 ditahan oleh tulangan tarik. Nilai kuat lekat ini sebagai acauan nilai kuat lekat yang terjadi pada balok menggunakan beton non pasir diharapkam mampu bekerja dengan baik hingga balok runtuh. Hasil Pengujiian geser friksi rerata yang dipeoleh 3,19 Mpa. Dari analisis balok komposit beton normal dengan non pasir diperoleh besar nilai geser friksi sebesar 1,47 Mpa sehingga kemampuan geser friksi yang terjadi pada balok komposit dapat menahan geser antara beton normal dengan non pasir. 


\subsection{Pengujian lentur balok BN-1, BNP-2 dan BK-1}

Dari Tabel 4 diketahui bahwa balok beton normal balok BN1 memiliki kapasitas paling besar dimana terjadi pada balok BNP-1 penurunan kapasitas sebesar $8.53 \%$ dan pada balok BK-1 sebesar 1.35\%. Pada balok BNP-1 dimungkinkan karena mutu beton pada balok BNP-1 yang sebesar 18,045 MPa mengakibatkan blok tekan yang dibutuhkan untuk mengimbangi blok tarik lebih besar sehingga jarak lengan kopel lebih kecil, berbeda dengan balok BN-1 sebesar 25,476 Mpa dan balok BK-1 sebesar 24,238 Mpa. Hasil eksperimen didapat nilai kuat lentur dapat dilihat pada Tabel 4.

Tabel 4. Prosentase peningkatan kuat lentur benda uji

\begin{tabular}{|c|c|c|c|c|c|}
\hline Benda Uji & $\begin{array}{c}\text { P Max } \\
(\mathrm{N})\end{array}$ & $\begin{array}{c}\text { M Max } \\
(\mathrm{Nmm})\end{array}$ & $\begin{array}{c}\text { Persentase } \\
(\%)\end{array}$ & $\begin{array}{c}\text { f'c flens }^{\prime} \\
(\mathrm{Mpa})\end{array}$ & $\begin{array}{c}\text { f'c web }^{\prime} \\
(\mathrm{Mpa})\end{array}$ \\
\hline BN - 1 & 129000 & 43000000 & 100,00 & 25,48 & 25,48 \\
\hline BNP-1 & 118000 & 39333333 & 91,47 & 18,05 & 18,05 \\
\hline BK - 1 & 127260 & 42420000 & 98,65 & 24,24 & 17,16 \\
\hline
\end{tabular}

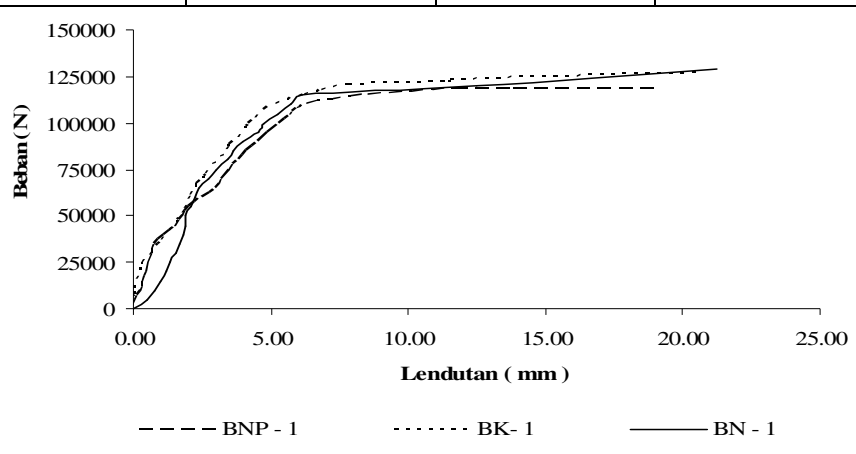

Gambar 7. Grafik Hubungan Beban - Lendutan masing-masing benda uji

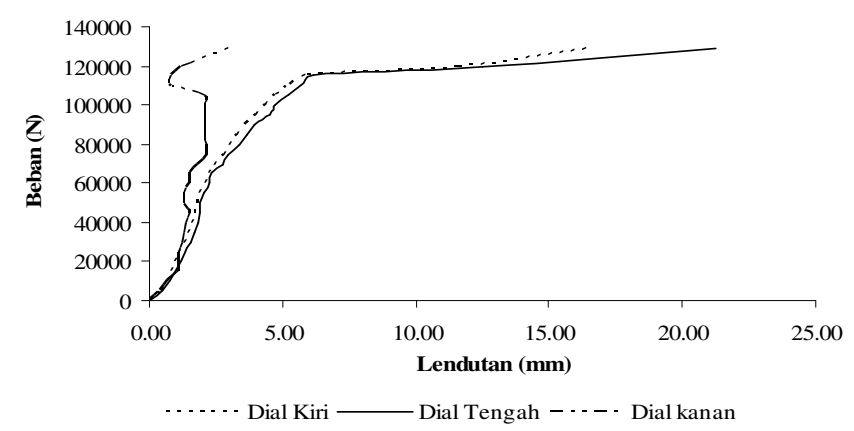

Gambar 8. Grafik hubungan beban - lendutan pada BN-1

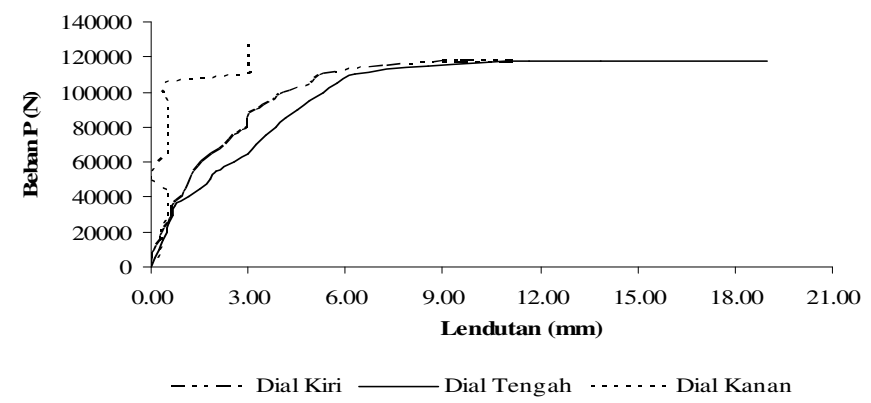

Gambar 9. Grafik hubungan beban - lendutan pada BNP-1 


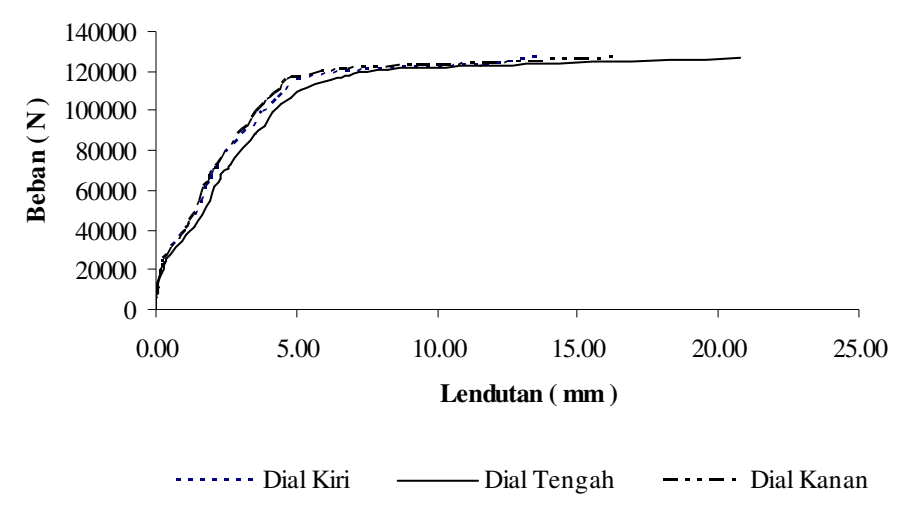

Gambar 10. Grafik hubungan beban - lendutan pada BK-1

\subsection{Daktilitas balok BN-1, BNP-2 dan BK-1}

Penurunan nilai daktilitas pada balok BK-1 sebesar 4,98\%, terhadap balok BN-1 sehingga nilai daktilitas balok $\mathrm{BN}-1$ dan balok $\mathrm{BK}-1$ masih bisa dikatakan relatif sama. Penurunan nilai daktilitas balok BNP-1 terhadap balok BN-1 sebesar sebesar $12,68 \%$ dikarenakan tidak daktail atau getas. Nilai daktilitas masingmasing balok uji secara lengkap dapat dilihat pada Tabel 5

Tabel 5. Daktilitas balok

\begin{tabular}{|c|c|c|c|c|}
\hline $\begin{array}{c}\text { Benda } \\
\text { Uji }\end{array}$ & $\begin{array}{c}\delta y \\
(\mathrm{~mm})\end{array}$ & $\begin{array}{c}\delta \mathrm{u} \\
(\mathrm{mm})\end{array}$ & $\begin{array}{c}\text { Daktilitas } \\
(\mathrm{U}=\delta \mathrm{u} / \delta \mathrm{y})\end{array}$ & $\begin{array}{c}\text { Prosentase } \\
(\%)\end{array}$ \\
\hline BN -1 & 6,120 & 21,250 & 3,47 & 100 \\
\hline BNP-1 & 6,260 & 18,980 & 3,03 & 87,32 \\
\hline BK - 1 & 6,230 & 20,770 & 3,33 & 96,02 \\
\hline
\end{tabular}

\subsection{Kekakuan lentur balok BN-1, BNP-2 dan BK-1}

Dari Tabel 6. nilai kekakuan pada balok BK-1 dan BNP-1 berturut-turut mengalami penurunan sebesar 1,46\% dan 6,49\% terhadap balok BN-1. Besar penurunan pada balok BK-1 masih relatif kecil terhadap balok BN-1, sedangkan pada balok BNP-1 terjadi perbedaan kekakuan lebih dari 5\% terhadap balok BN-1 dakibatkan modulus elastisitas pada balok BNP-1 yang terjadi masih lebih kecil dari balok BN-1. Terhadap hasil pengujian lentur balok, nilai kekakuan secara lengkap dapat dilihat pada Tabel 6.

Tabel 6. Nilai kekakuan lentur balok

\begin{tabular}{|c|c|c|c|c|}
\hline $\begin{array}{c}\text { Benda } \\
\text { Uji }\end{array}$ & $\begin{array}{c}\text { Py } \\
(\mathrm{N})\end{array}$ & $\begin{array}{c}\text { Lendutan } \\
(\mathrm{mm})\end{array}$ & $\begin{array}{c}\text { Kekakuan } \\
(\mathrm{N} / \mathrm{mm})\end{array}$ & $\begin{array}{c}\text { Prosentase } \\
(\%)\end{array}$ \\
\hline BN - 1 & 115000 & 6,120 & 18790,85 & 100 \\
\hline BNP-1 & 110000 & 6,260 & 17571,88 & 93,51 \\
\hline BK - 1 & 115360 & 6,230 & 18516,85 & 98,54 \\
\hline
\end{tabular}

\subsection{Perbandingan kuat lentur hasil eksperimen dan teoritis}

Dari hasil masing-masing benda uji didapatkan kapasitas balok hasil eksperimen lebih besar dibandingkan dari hasil analisis tampang (integral) ataupun cara SNI. Hasil eksperimen masing-masing benda uji mengalami kenaikan karena adanya faktor penambahan kekuatan (over strength factor) yaitu bertambahnya besar kuat tekan dan regangan tekan maksimal beton disebabkan 
beberapa hal: terjadi adanya pengekangan yang baik antara tulangan dengan beton itu sendiri, Tulangan sengkang (begel) mengekang inti penampang balok secara keseluruhan. Kapasitas saat eksperimen pada balok BN-1, BK-1 dan BNP-1 hampir sama karena tipe balok $\mathrm{T}$ didesain berprilaku tegangan tekan yang bekerja hanya pada bagian sayap. Hasil eksperimen dan teoritis dapat diperlihatkan pada Tabel 7 .

Tabel 7. Perbandingan hasil eksperimen dengan teoritis untuk BN-1

\begin{tabular}{|l|l|c|c|c|c|}
\hline \multicolumn{2}{|c|}{ Keterangan } & Pre-Crack & Yield & Ultimit & $\begin{array}{c}\text { Ultimit } \\
(\text { SNI })\end{array}$ \\
\hline \multirow{2}{*}{$\begin{array}{l}\text { Tegangan beton } \\
\text { tarik }(f c), \mathrm{N}\end{array}$} & Teoritis & 1,104 & - & - & - \\
\cline { 2 - 6 } & Hasil Lab & 1,104 & - & - & - \\
\hline \multirow{2}{*}{ Beban $(\mathrm{N})$} & Teoritis & $12114 ., 29$ & 71237 & 88160 & 89007 \\
\cline { 2 - 6 } & Hasil Lab & 10000 & 115000 & 129000 & 129000 \\
\hline \multirow{2}{*}{ Momen $(\mathrm{Nmm})$} & Teoritis & 4038043 & 29999265 & 30126774 & 29668997 \\
\cline { 2 - 6 } & Hasil Lab & 3333333 & 38333333 & 43000000 & 43000000 \\
\hline
\end{tabular}

Tabel 8. Perbandingan hasil eksperimen dengan teoritis untuk BK-1

\begin{tabular}{|l|l|c|c|c|}
\hline \multicolumn{2}{|c|}{ Keterangan } & Pre-Crack & Yield & Ultimit \\
\hline \multirow{2}{*}{ Beban (N) } & Teoritis & 5724 & 69298 & 87954,4 \\
\cline { 2 - 5 } & Hasil Lab & 5880 & 115360 & 127260 \\
\hline \multirow{2}{*}{ Momen (Nmm) } & Teoritis & 1908124 & 23099358 & 29318126 \\
\cline { 2 - 5 } & Hasil Lab & 12566667 & 38453333 & 42420000 \\
\hline
\end{tabular}

Tabel 9. Perbandingan hasil eksperimen dengan teoritis untuk BNP-1

\begin{tabular}{|l|l|c|c|c|}
\hline \multicolumn{2}{|c|}{ Keterangan } & Pre-Crack & Yield & Ultimit \\
\hline $\begin{array}{l}\text { Tegangan beton tarik } \\
(f c t), \mathrm{N}\end{array}$ & Teoritis & 1,097 & - & - \\
\cline { 2 - 5 } & Hasil Lab & 1,097 & - & - \\
\hline \multirow{2}{*}{ Beban $(\mathrm{N})$} & Teoritis & 12236 & 73329 & 87431 \\
\cline { 2 - 5 } & Hasil Lab & 10000 & 110000 & 118000 \\
\hline \multirow{2}{*}{ Momen (Nmm ) } & Teoritis & 4078582 & 24442844 & 29386500 \\
\cline { 2 - 5 } & Hasil Lab & 15000000 & 36666667 & 39333333 \\
\hline
\end{tabular}

\subsection{Pola retak dan keruntuhan}

Pada balok BN-1, balok BNP-1 dan BK-1 terjadi retak dimulai dari tengah bentang sampai sepertiga panjang balok dan retak terus bertambah merambat keatas atau tegak lurus terhadap arah tegangan utama sehingga retak awal yang sudah terjadi akan semakin melebar dan semakin menuju sumbu netral penampang dengan penambahan beban yang diberikan. Hal ini bersamaan dengan semakin besarnya lendutan di tengah bentang. Melihat masing-masing keruntuhan terjadi dari balok-balok dikategorikan sebagai keruntuhan lentur.

\section{Kesimpulan}

Dari hasil penelitian dan pembahasan maka dapat diambil beberapa kesimpulan sebagai berikut: 
1. Kemampuan beban balok BN-1 terbesar dibandingkan dengan balok BNP-1 dan balok BK-1. Pada balok BNP-1 kemampuan beban mengalami penurunan sebesar $8,35 \%$ terhadap balok BN-1.

2. Kapasitas momen balok BN-1 sebesar 43000000 Nmm, balok BK-1 sebesar 42420000 Nmm dan balok BNP-1 sebesar 39333333 Nmm. Prosentase kemampuan kapasitas antara balok $\mathrm{BN}-1$ dengan $\mathrm{BK}-1$ yang dicapai relatif sama yaitu selisih $1,35 \%$ dan hanya pada balok BNP-1 terjadi penurunan kemampuan sebesar 8,35\% terhadap balok BN-1

3. Penurunan nilai daktilitas balok berturut-turut untuk balok BK-2 dan BNP-2 mencapai 4,92\% dan 12,68\%. Pada balok BNP-1 betonnya cenderung lebih getas sehingga lendutan ultimit lebih cepat terjadi.

4. Nilai kekakuan lentur balok BN-1, BK-1, BNP-1 relatif sama, dengan prosentase sebesar 98,.54\% dan 93,51\% berturut-turut untuk balok BK-1 dan balok BNP-1 terhadap balok BN-1 sehingga pada aksi beton normal cenderung lebih kaku daripada beton non pasir, memiliki lekatan lebih baik dengan tulangan sehingga terjadi aksi komposit yang lebih baik antara baja dan beton.

5. Besar nilai kuat lekat baja tulangan diameter $12 \mathrm{~m}$ dengan beton non pasir sebesar 8,1848 $\mathrm{MPa}$ dan benda uji pull out hancur pada penarikan beban maksimum sebesar 45983,33 N.

6. Gaya geser friksi diperoleh sebesar 2,111 $\mathrm{MPa}$ dan mampu menahan geser antara beton normal dengan non pasir akibat beban luar sebesar 1,470 $\mathrm{MPa}$ pada balok komposit.

7. Pola retak masing-masing benda uji mengalami keruntuhan lentur

Rekomendasi yang dapat diberikan berdasarkan kapasitas pada balok BN-1, BK-1 dan BNP-1 dimana blok tekan beton di dalam flens terutama pada pada balok BK-1 dan BNP-1 bisa dicoba pada bagian badan diisi material beton non pasir dengan perbandingan berat lebih kecil dari 1:2.

\section{Daftar Kepustakaan}

1. Anonim, 1990, Tatacara Pembuatan Rencana Campuran Beton Normal SKSNI T-15-1990-03, Yayasan Penyelidikan Masalah Bangunan, Departemen Pekerjaan Umum, Bandung

2. Gere, J.M., Timoshenko, S.P, 1972, Mechanics of Material, Brooks/Cole, Engineering Division, California

3. Park,R., Paulay, T, 1975, Reinforced Concrete Structures, John Willey \& Sons, New York

4. Somayaji, S, 1995, Civil Engineering Maerial, Prentice Hall, Englewood, Cliffs, New Jersey

5. Subkhannur, A, 2002, Penggunaan Kerikil Asal Gunung Merapi Sebagai Agregat Dalam Pembuatan Beton Non Pasir, Tugas akhir, Universitas Gadjah Mada Yogyakarta

6. Tjokrodimuljo, K, 1995, Kekuatan dan Daltilitas Balok Bertulang Dari Beton-Non-Pasir Dengan Kerikil Lempung Bekah, Media Teknik No1 Tahun XVII, Edisi April 1994

7. Wang, C, dan Salmon, C.G, 1994, Reinforced Concrete Design, terjemahan Hariandja B, Edisi keempat, penerbit Erlangga, Jakarta 